\title{
Transformations of the Plane: Study of Bionic Architectural Models of Anton Vranka
}

\section{Premeny plochy: Štúdia bionických modelov architekta Antona Vranku}

Jakub Novák

Ústav prostorové tvorby, Fakulta architektury, Vysoké učení technickév Brně, Česká republika xanovakj@stud.fa.vutbr.cz

\begin{abstract}
Structural modelling techniques of architect and professor Anton Vranka influenced, in a specific way, several generations of students at the Faculty of Architecture of STU in Bratislava.

The phenomenon of "Vrankovina" - a problem, puzzle, or proposal that thrives on geometry, uses the effect of optical illusions, or transforms any flat medium into a surprising spatial structure - is still known among the students and graduates, a few years after Vranka retired.

His unique approach creates links between the Bauhaus theory of architecture, architectural bionics and biomimetics, the fascinating directions in architectural theory of the 1960s through the 1980s.

The aim of this paper is to capture the knowledge stored in Vranka's fragile paper models, and report on his motives and methods and theoretical works. Thus, they will be added to the growing body of works on folded architecture.

The systemization proposed documents an astounding variety of forms, created within just a few creative processes. The categorization of the models will be used as a basic platform for transferring theoretical works to architectural building practice.
\end{abstract}

KEYWORDS: architectural bionics; folded architecture; origami; kirigami; stereotomic structures

ABSTRAKT: Štruktívne modelovanie slovenského architekta a pedagóga Antona Vranku špecifickým spôsobom ovplyvnilo niekolko generácií študentov pripravujúcich sa na Fakulte architektúry STU v Bratislave na povolanie architekta. Fenomén 
tzv. Vrankoviny, problému, hádanky alebo návrhu, ktorý sa vyžíva v geometrii, využíva optický klam alebo pretvára plošné médium na prekvapivú priestorovú štruktúru, sa medzi študentmi a absolventmi traduje ešte dnes, niekolko rokov po Vrankovom odchode na dôchodok.

Jeho jedinečný prístup k teórii architektúry spája odkaz Bauhausu s prúdom architektonickej bioniky a biomimetiky, fascinujúcich smerov v architektonickej teórii 60 . až 80. rokov 20. storočia.

Cielom tejto práce je zachytit poznanie uložené vo Vrankových krehkých papierových modeloch a podat správu o jeho motívoch a metódach. Zdokumentovaním východísk a teoretických prác sa tieto poznatky pridajú do rastúceho kruhu zdrojov pojednávajúcich o skladanej architektúre.

Uvedená systemizácia používaných vyjadrovacích prvkov dokumentuje ohromujúcu pestrost' foriem vychádzajúcu iba z niekol'kých tvorivých prostriedkov. Z nej vychádzajúca kategorizácia výsledných modelov v rámci tohto výskumu poslúži ako báza pre skúmanie možností prenesenia teoretických prác do stavebnej praxe.

KLÍČOVÁ SLOVA: architektonická bionika; skladaná architektúra; origami; kirigami; stereotomické štruktúry

\section{Úvod}

Anton Vranka je priekopníkom bionického architektonického modelovania založeného na pretváraní plošného média na priestorové kompozície.

Štyri desatročia pôsobil ako pedagóg na Fakulte architektúry Slovenskej technickej univerzity v Bratislave, kde vytváranie modelov začlenil do procesu formovania mladých architektov. Jeho záujem o geometriu v kontexte vytvárania architektonického diela dokladujú ním vyučované predmety ako architektonická kompozícia, výtvarná geometria, perspektíva alebo farba.

Tento článok je venovaný štúdiu inšpirácií, metód a prostriedkov spojených s jeho papierovými modelmi a náčrtu ich možnej kategorizácie. Takisto sa snaží začlenit Vrankovu vedeckú prácu do medzinárodného kontextu načrtnutím niekolkých paralel jeho bádania s tvorbou zahraničných autorov.

\section{Východiská a perspektíva}

Práce Antona Vranku a jeho žiakov vznikali v stave informačnej izolácie od diania vo svete skladanej origamickej architektúry v západných krajinách a Japonsku. Vy- 
chádzajú z odlišnej paradigmy než dnes dobre zdokumentované základné práce na tomto poli. Je preto velmi obohacujúce sledovat tvorivý proces, ktorým Vranka so žiakmi prichádzali k podobným záverom a formám ako ich kolegovia v zahraničí. Ich modely sú porovnatelné s prácami Ronalda D. Rescha, ktorý bol na prelome 60 . a 70. rokov jedným z najaktívnejších architektov študujúcich priestorové možnosti topologických návrhov (Resch 1973, s. 643). Zároveň sú vnímaví k štruktívnej jednote svojich návrhov, aspektu, pre ktorý sa o skladanú architektúru koncom 20. storočia zaujímal napríklad architekt Peter Eisenman, ktorého diela do híbky rozoberá Greg Lynn vo svojej eseji Folding in architecture (Lynn 2004, s. 111). Lynn v nej argumentuje, že skladanie je pri vytváraní komplexných architektonických diel hlavne nástrojom harmonizácie.

Modely, ktoré za desatročia Anton Vranka vytvoril, sa svojou formálnou pestrostou vychádzajúcou zo štruktívnej podstaty modelovania tuhého listu vymykajú hlavnému prúdu československej a neskôr slovenskej teórie architektúry a stavebnej praxe. Spojením konštruktivistických postupov práce s papierom a hladaním inšpirácie $\mathrm{v}$ prírodných systémoch majú jeho skladané kompozície mnoho spoločné so súčasným dielom významných svetových architektov a dizajnérov ako sú UN-studio, Rem Koolhaas a Frank O. Gehry (Mückenheim a Demel 2012, s. 269).

Hlavným východiskom pri hladaní nových architektonických foriem a štruktúr bola pre Vranku geometria vystupujúca z prírody. V rámci vyučovania kompozície hladal možnosti dialógu medzi klasickými kompozičnými kategóriami a súdobým prúdom architektonickej bioniky - aplikovania prírodných kompozičných princípov vo vytváraní ludského životného prostredia. Podla vlastných slov tým na tomto poli nadväzuje na prácu architektov Frei Otto a J. S. Lebedeva (Vranka 2014).

Vranka čerpá z odkazu Josefa Albersa zo školy Bauhaus, v súlade s ktorým používa vytváranie modelov ako prostriedok rozvíjania predstavivosti, tvorivosti a svedomitosti študentov architektúry. Skladanými modelmi popisujú priestor a vedú dialóg medzi svojimi predstavami a reálnym výtvorom, pričom hmatová skúsenost’ s materiálom hrá v celom procese zásadnú úlohu. Ako sám píše o nepredvídatelnom správaní papiera pri skladaní vo výučbe: „Tieto deformácie majú mimoriadny význam pre rozvíjanie tvorivej fantázie, je to pre nás jav, ktorý považujeme za jeden z najcennejších,“ (Vranka et al. 1984, s. 23). Vrankov prístup k výučbe je v praxi vel’mi podobný taktilnej návrhovej metóde používanej na Ústave priestorovej tvorby brnenskej Fakulty architektúry (Novák a Palacký 2015).

Vranka sa nikdy aktívne nezaujímal o origami, umenie skladania z papiera, alebo kirigami, umenie rezania tohto média. Nemal v svojom najtvorivejšom období technické možnosti preskúmat matematickú a kinetickú podstatu správania svojich mo- 
delov. Prenos jeho ideových návrhov dokumentovaných modelmi z papiera do ludskej mierky bol v nedohladne a použitie ním skúmaných princípov skladania sa v československej architektúre realizovalo výhradne vo forme masívnych železobetónových lomeníc. Jeho výtvory vychádzajú z nadšenia a tvorivosti spojených s prácou s papierom. S nedávnym rozvojom $v$ materiálovom inžinierstve a CAM technológiách sú dnes tieto teoretické práce konečne prakticky realizovatel’né. Pretváranie plošného média na priestorové štruktúry je $\mathrm{v}$ architektúre použitelné $\mathrm{v}$ širokej škále mierok a materiálových riešení od lahkých rozkladatelných prístreškov z vylahčených sendvičových panelov, cez konštrukcie z robotom frézovaných KLH dosiek z masívneho dreva, až po ferrocement a iné cementové kompozity vystužené textilnými vláknami.

Napriek tomu, že sa jedná o kvalitné a pokrokové práce, nie sú dostatočne zdokumentované. Štúdium týchto modelov a pracovných postupov doplña dnešnú systemizáciu skladacích techník a systémov pre dizajnérov ako aj historický prehlad autorov, ktorí sa zaslúžili o rozvoj tejto témy v architektonickom navrhovaní.

\section{Metódy}

\section{Prístup k téme}

Vranka vníma modelovanie ako formu experimentu. Ide o dialóg, v ktorom autor zachytí svoju myšlienku formou geometrickej osnovy - rovinného plášta (angl. crease pattern), a papier svojimi fyzikálnymi vlastnostami odpovie v reči topografie počas skladania do priestoru. Autor následne pozmení svoju predstavu a celý proces sa opakuje, až kým nie sú tieto dva póly v súlade. Hladanie možností a základných vlastností správania papiera je rovnako ako v práci Ronalda D. Rescha (Resch a Armstrong 1971) základným prostriedkom jeho vedeckej práce. Papier v tomto procese slúži ako symbol plošných materiálov používaných v stavebnej praxi. Diskrepancia v spôsobe odolávania zat̉aženiam modelu a výsledného architektonického diela je najčastejším dôvodom pochýb o použitel’nosti princípu skladania. Je skutočne dôležité vnímat limity reprezentácie modelom a overovat poznatky z jeho skúmania špecializovanými výpočtovými nástrojmi určenými na posúdenie statického pôsobenia štruktúry.

\section{Pracovné postupy}

Vranka vytvára priestorové modely z rovinného formátu papiera. On sám to nazýva modelovaním z rovinného základu, tvarovaním tuhého listu (Vranka 2014) alebo premenou roviny na stereotomický útvar (Vranka et al. 1984, s. 23). Na prechod $\mathrm{z}$ dvoch do tretieho rozmeru používa nasledujúce základné prostriedky.

Prvým z nich je zlom alebo sklad (angl. fold), kedy je papier ostro zložený podla 
priamočiarej alebo krivočiarej línie. Na vyznačenie zlomovej línie používa Vranka techniku narezania, kedy materiál z jednej strany oslabí - nareže skalpelom. Materiál narezáva vždy na strane hrebeňa (angl. mountain fold), vonkajšej strany papiera, ktorá je skladaním tahaná. Väčšina jeho modelov obsahuje zlomy hrebeňové, ktoré narezáva z hornej strany papiera, aj údolné (angl. valley fold), pre narezanie ktorých musí formát otočit a narezat $\mathrm{z}$ druhej strany. Vrcholy skladačky, body, v ktorých sa zlomy stretávajú, si obojstranne značí prepichnutím papiera hrotom kružidla.

Pre oslabovanie materiálu, nutnost̉ narezávania z dvoch strán a pre riziko odštiepenia horných vrstiev papiera počas skladania sa tento proces obecne používa zriedkavo. Častejšie je uvádzaný postup rylovania, kedy je materiál z jednej strany stlačený tupou stranou modelárskeho noža alebo špeciálnym nástrojom s oblou špičkou. Vranka však narezávanie používa na všetkých modeloch.

Kruhové zlomy vytvára kružidlom s dvomi hrotmi. Jeden určuje stred opisovanej kružnice, druhý narušuje vlákna materiálu po obvode kružnice alebo jej časti. Tým znižuje tuhost̉ materiálu v mieste skladu. Ako špeciálnu formu zlomu radí Vranka prerezanie skrz materiál alebo vyrezanie časti formátu.

Ďalším základným prostriedkom je ohyb do valca (angl. bend - ohnút), ktorý pozostáva z plynulého ohnutia materiálu do valcovej plochy. Od zlomu sa líši tým, že deformácia má istý, po celej dížke deformačnej línie konštantný, rádius.

K nemu príbuzný je posledný prostriedok, skrútenie do kužela, ktorý spočíva v plynulom ohnutí papiera do kuželovej plochy. Od predchádzajúceho sa líši postupnou zmenou polomeru na línii deformácie. Valcovým a kuželovým ohýbaním je možné vytvárat mäkko pôsobiace modely alebo vytvorit kontrast medzi ostrou hranou zlomu a postupným priebehom plochy ohybu.

Rozšírením týchto princípov môže byt použitie kuželosečiek pre zlomovú líniu alebo pre profil ohýbania. Vrankov hlavný záujem nespočíval v hladaní konkrétnych nových foriem, ale v skúmaní postupov teoretických možností modelovania z rovinného základu - hladaní limitov tvorivých možností. Preto a takisto pre konštrukčnú jednoduchost používa z kriviek výhradne kružnicu.

\section{Systemizácia prostriedkov do abecedy}

Popísané základné prostriedky Vranka použil na vytvorenie istej systemizácie prvkov, ktorú metaforicky nazýva abecedou4. Prvky abecedy vznikajú kombináciou priamočiareho a kružnicového skladu, rezu a valcového a kuželového ohybu. Základným znakom týchto atomárnych prvkov je použitie štvorcového formátu papiera. 
Abeceda sa dá rozdelit na rodiny alebo rady príbuzných motívov s podobnými znakmi. Typický rad začína použitím základného princípu, ako je polkruhový zlom so stredom na hrane formátu, a dalej sa rozvíja. Podla toho, či sa tento rozvoj realizuje násobením pôvodného prvku (napr. zdvojením polkruhového zlomu so stredom na hrane formátu), alebo vnorením príbuzného prostriedku do vnútra už aplikovaného, vznikajú vetvy prvkov. Tie bývajú založené na rôznych kompozičných princípoch, čo znovu svedčí o Vrankovej zálube v geometrickej kompozícií.

Abeceda obsahuje niekolko tradičných foriem origami, ako je akordeónový sklad, reverzný sklad (V-fold) alebo water-bomb základňa (angl. base). Nejedná sa o inšpiráciu japonským skladaním papiera, ale o logický výsledok systematickej analýzy geometrických možností práce s týmto médiom. Prvky abecedy je možné kombinovat’ a krížit, čím vznikajú komplexnejšie motívy a modely.

\section{Štúdium a kategorizácia modelov}

Spomínaná abeceda prostriedkov je však iba jedným zo zdrojov pestrosti Vrankovej tvorby. Jednotlivé písmenká je totiž možné použit s viacerými priestorotvornými zámermi. Podla spôsobu pretvárania plochy môžeme väčšinu Vrankových modelov zatriedit’ do jednej z nižšie popísaných kategórii.

\section{Rotačné vztyčujúce sa systémy}

Rotačné vztyčujúce sa systémy vznikajú ortogonálnym alebo radiálnym radením zlomu a prerezania plošného média. Nosnou jednotkou štruktúry je sústava rámp, ktorých sklon sa pri rotačnom pohybe modelu zvyšuje. Pôdorysné rozmery štruktúry zostávajú pri krútivom pohybe nezmenené, zvyšuje sa iba jej výška. Rebrá štruktúry sa pri skladaní naklápajú z pôvodnej horizontálnej do staticky výhodnej vertikálnej orientácie.

Použité sklady sú výhradne priamočiare. Rezové línie na seba môžu brat’ ale i krivočiaru alebo zmiešanočiaru podobu. Vnútorný priestor objektu, ako aj jeho tvar pri pohlade zvonku, je definovaný práve prebehom týchto rebier. Z radiálneho usporiadania rebier vyplýva organická previazanost' interiéru a exteriéru skladby, vnútorné a vonkajšie hrany susediacich nosných prvkov sa stretávajú v jednej rezovej krivke. Naopak na kinetické správanie systému majú prebehy rebier iba druhotný vplyv a je určené konfiguráciou skladových línií na pätách rebier. Volnost̉ pri volbe charakteru rezovych línii prináša pestrost̉ tvorených foriem a umožňuje prácu s ornamentom.

Názov pre túto kategóriu (angl. Rotational Errection Systems, skr. RES) skladaných 
modelov zaviedol a do hĺbky ich popísal v roku 2014 japonský architekt a akademik Yoshimura Miyamoto (Miyamoto 2014). Vo svojom článku zdôrazňuje príbuznost’ týchto modelov a Pop-up techník využívajúcich jediný list papiera. Zaujímavostou je, že v tej istej práci uvádza, že vyskakovacie Pop-up modely skúmal už Josef Albers pri výučbe na škole Bauhaus v 20. rokoch 20. storočia.

\section{Prúžková kompozícia}

Podobne ako RES modely, prúžkové kompozície využívajú vo vel'kej miere delenie plochy rezaním. Hlavným skladobným prvkom kompozície sa tu stáva lineárny prúžok papiera, prípadne séria navzájom spojených prúžkov. Nakolko tieto prvky umožňujú volné skladanie a ohýbanie, vznikajú týmto postupom sviežo pôsobiace kompozície. Komplexnost’ vzniknutých štruktúr zdôrazňuje fakt, že pre každý rozvinutý plášt popisujúci polohu rezov a skladov existuje nekonečné množstvo priestorových konfigurácii popisovaného modelu.

Pre interpretáciu výsledných motívov v tuhom materiáli je nutné reagovat na odlišné statické pôsobenie štruktúry $\mathrm{v}$ mierke papierového modelu a v mierke architektúry s použitím zažitých stavebných technológií.

Z toho je možné vyvodit, že v porovnaní s ostatnými v tomto texte popisovanými metódami pretvárania plochy na priestor sa jedná o najmenej štruktívny kompozičný princíp. Jeho využitie sa ponúka hlavne v skorších štádiách návrhu na fyzickú reprezentáciu zložitejších štruktúr, ktoré môže byt inak zložité, prácne, alebo drahé zachytit’ modelom. Môže poslúžit na jednoduché modelovanie dvojsmerne zakrivených plôch, priestorových mriežok a iných priestorovo tažko uchopitelných foriem. Ide o vel'mi rýchlu metódu s nesmiernym tvorivým potenciálom. Doslova otvára oči pred širokými možnostami tvarovania plochy.

Pri výučbe ju na škole architektúry v Holandskom Delfte využíva napríklad Sophia Vizoviti (Vyzoviti 2010, s. 141), ktorá s jej pomocou nadchýna študentov pre hladanie nových ciest v navrhovaní a generovaní komplexných priestorových plôch.

\section{Opakovanie reverzného skladu v rozvinutel'ných priestorových sietach}

Reverzný sklad (alt. V-sklad) vzniká odvodením od skladu harmonikového. Výsledné štruktúry často tvoria ortogonálne alebo radiálne oblúky a klenby. Geometrické a topografické vlastnosti reverzného skladu a z neho tvorených štruktúr do hĺbky študuje a v stavebnej praxi drevenej architektúry overuje Hans Ulrich Buri vo svojej dizertačnej práci Origami - Folded plate structures (Buri 2010, s. 275). 
Podla spôsobu radenia reverzného skladu v ploche, ako je posunutie, otočenie, zrkadlenie a ich kombinácie, vznikajú tri hlavné rodiny priestorových sietí: Miura-Ori, Yoshimura-Ori a Diagonal Pattern. Všetky tri nachádzame vo Vrankovej tvorbe v nespočetných variantách a kombináciách. Dnes sa jedná o tri najčastejšie používané skladané štruktúry v architektúre a dizajne. Dôvodov pre túto skutočnost̉ je hned niekolko. Tieto modely majú po stránke štruktúry najbližšie k známym lomenicovým stavbám. Ich použitie pre navrhovanie stavieb sa preto akoby ponúka. Rozvinutel'nost’ týchto sietí a ich zložitelnost' do plochy často tvorcov inšpirujú k počinom smerujúcim ku kinetickej architektúre a menej hmotným technológiám. Ako príklad poslúžia viaceré prípadové štúdie pevných alebo skladatelných pavilónov z lepených drevených dosiek z masívneho reziva, vylahčených vrstvených panelov alebo lisovaného plechu.

Vranka, rovnako ako dnešní tvorcovia pracujúci s týmito princípmi, vycítil ich potenciál a jeho práce sa uberajú vyššie popísaným smerom. Je nutné zdôraznit, že v dobe vzniku Vrankových modelov sa jednalo o jednoznačne okrajové fenomény architektonickej tvorby. Na ich príklade sa zase ukazuje híbka a vytrvalost' Vrankovho záujmu o abstraktný svet skladaných modelov.

Dnes sa pre prácu s návrhmi odvodenými od reverzného skladu zaužívalo používanie pokročilých výpočtových nástrojov a CNC výrobných postupov. Velkej oblube sa tešia parametrické návrhové nástroje ako modul Grasshopper.

\section{Waterbomb}

Poslednou kategóriou modelov pokrytých v tomto článku sú práce príbuzné origamickej báze Waterbomb. Bázami sa v svete origami nazývajú základné modely, z ktorých sú odvodené mnohé d’alšie skladačky. Waterbomb je základom množstva modelov (Lang 2003, s. 598). Vyznačuje sa vytvorením vnútorného priestoru, čo ju robí zaujímavým objektom architektonického skúmania.

Ako argumentuje Brandon Hanna a kolektív (Hanna et al. 2014), na poli aplikovaných prác inšpirovaných skladaním v rôznych odboroch vedy a techniky (tzv. Origamics) je waterbomb najčastejšie sa objavujúcim kinetickým mechanizmom.

Základná podoba waterbomb pozostáva zo štvorcového formátu zloženého dvomi pármi priamočiarych skladov. Dva sklady spájajú stredy strán formátu a dva prechádzajú jeho diagonálami. Všetky štyri sa pretínajú v strede formátu vo vrchole bázy.

Vrankov pohlad na modely $\mathrm{v}$ tejto kategórii je zacielený na vytváranie stabilných kompozícii, ktore podobnostou stanovej streche evokujú architektúru. Ako už bolo zmienené, Vranka sa o origami nikdy nezaujímal, dá sa teda usudzovat', že na water- 
bomb narazil pri systematickom základnom výskume pretvárania plochy. S modelmi pracuje s jemným citom umelca. Využíva zmenu v hustote skladov, čím časti konštrukcie vylahčuje. Iné zase pridaním hmoty štruktívne zdôrazňuje, čím podčiarkuje ich nosný charakter.

$\mathrm{Na}$ obrázku jeho modelov vychádzajúcich $\mathrm{z}$ waterbomb vidíme dva odlišné modely, oba spojené s iným prvkom skladania. Jeden je obohatený zmnoženým reverzným skladom pre zvýšenie únosnosti konštrukcie. Pri druhom použil sklady vedúce po výseku kružnice, čím vytvára vel’mi podobnú kompozíciu ako priekopník krivočiareho skladania a Vrankov súčasník zo zámoria David Huffman (Demaine et al. 2011). Na týchto príkladoch môžeme doložit tvorivé kríženie skladaných motívov, ktoré je pre Vrankovu bioniku typické.

\section{Záver}

V článku boli predstavené základné východiská, metódy práce a hlavné osi záujmu slovenského architekta a akademika Antona Vranku na poli skladanej architektonickej bioniky. Prezentované boli štyri základné modelové rodiny vyskytujúce sa naprieč Vrankovou tvorbou. Dokumentácia jeho prác odhalila širokú pestrost̉ motívov jeho tvorby, ktorá vychádza z čistej zvedavosti a fascinácie abstraktným svetom geometrie. Jeho práce aj dnes pôsobia ako ostrov pokoja a poriadku, územie nezatažené dobovými trendami ani akoukolvek propagandou, miesto pre realizáciu tvorivosti inšpirovanej láskou k prírode a geometrii.

Jeho dlhodobý záujem zacielený na pretváranie plochy do priestoru sa vyznačuje systematickým skúmaním jednotlivých vetiev bionického modelovania. Jeho práce je ešte dnes možné začlenit do aktuálneho diania na poli skladanej architektúry a dizajnu. Ich nadčasovost' a bohatost' môže teda stále inšpirovat' k d’alšiemu štúdiu.

Ďalším logickým krokom je skúmanie uplatnenia kompozičných princípov a tvorivých metód pri realizácii skutočnej skladanej architektúry v ludskej mierke. Skúmané modely Antona Vranku sa líšia potenciálom prenosu do fyzickej podoby a skutočnej mierky architektúry. Ako východisko sa ponúkajú modely z kategórie opakovaných reverzných skladov a modely z rodiny waterbomb, ktoré svojimi klenutými kompozíciami a prelamovanými stenami prinášajú stabilitu a tuhost', a ktorých spojenie s modernými technológiami tenkostenných cementových kompozitov má v už Európe za sebou prvé úspešné experimenty.

\section{Pod'akovanie}

Ďakujem kolegovi Antonovi Vrankovi za súčinnost’ počas výskumu, poskytnutie 
obrazovej dokumentácie svojich modelov a zdielanie svojich úvah. Článok vznikol s podporou VUT v Brne, projektmi Metodológia architektonického návrhu v kontexte bionickej architektúry Antona Vranku č. J-FA-15-2884 a projektom 100. výročia vzdelávania architektov na Fakulte architektúry VUT v Brne č. FA-S-16-3727.
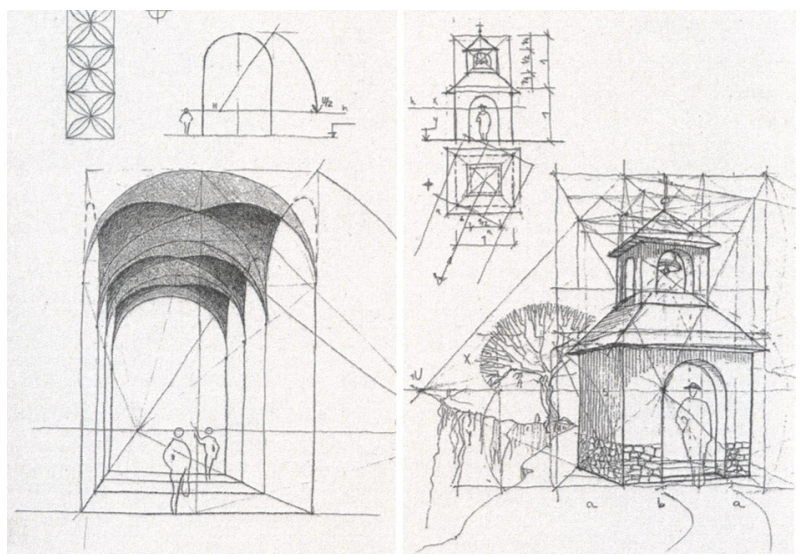

Obr. 1. Perspektívne kresby Antona Vranku (Autor a zdroj: Anton Vranka)

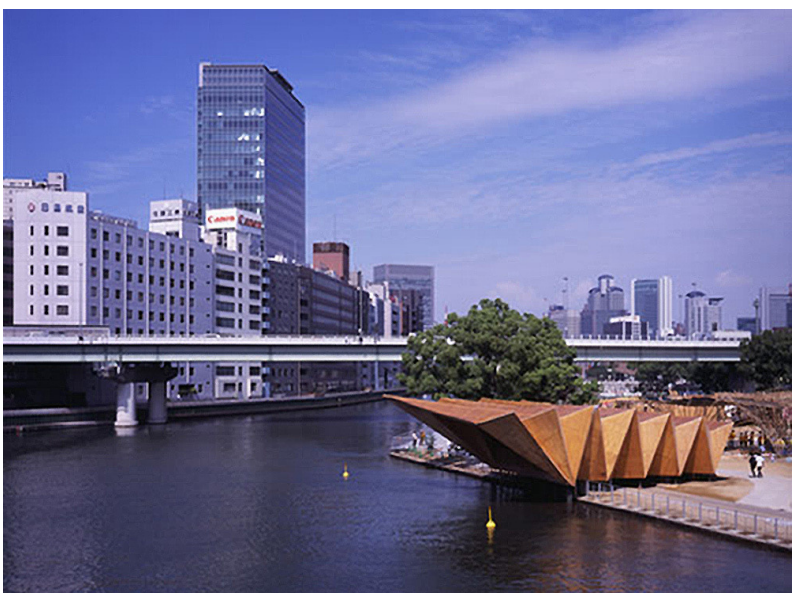

Obr. 2. Dočasný lomenicový prístrešok v Osake z frézovaných masívnych drevených dosiek KLH. Autor a foto: Ryuichi Ashizawa Architects (Zdroj: pleatfarm.com) 


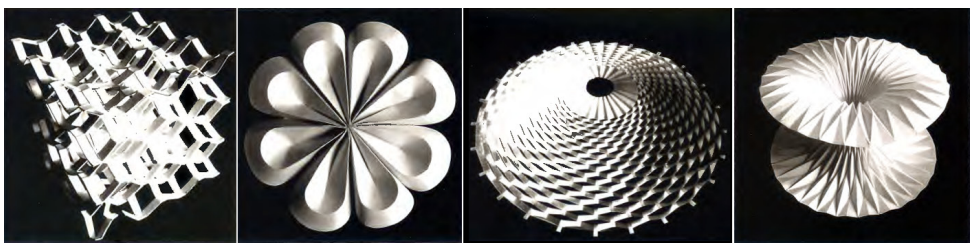

Obr. 3. Štyri príklady modelov. Zlava: priestorová siet', modulárna krivočiara ružica, špirálová kupola - rotačný vztyčovací systém, radiálna diamantová kompozícia - v-sklad (Autor a zdroj: Anton Vranka)

1

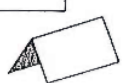

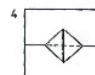

4
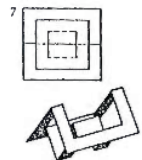

Dnf

4

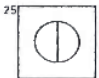

250
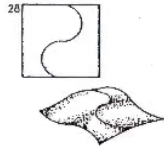

\begin{tabular}{|l|l|}
\hline & 1 \\
\hline & \\
\hline
\end{tabular}
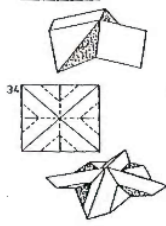

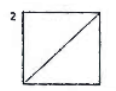

2

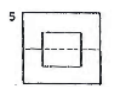

4-9
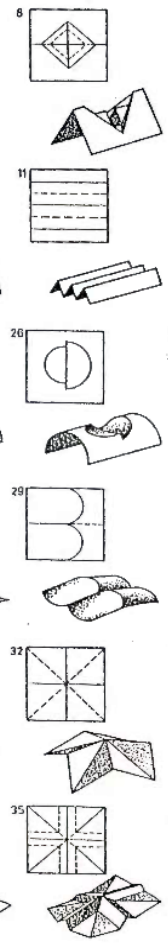
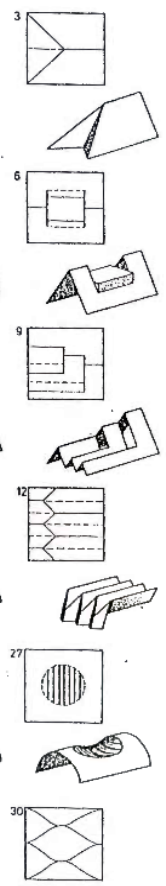

7
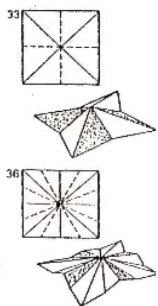
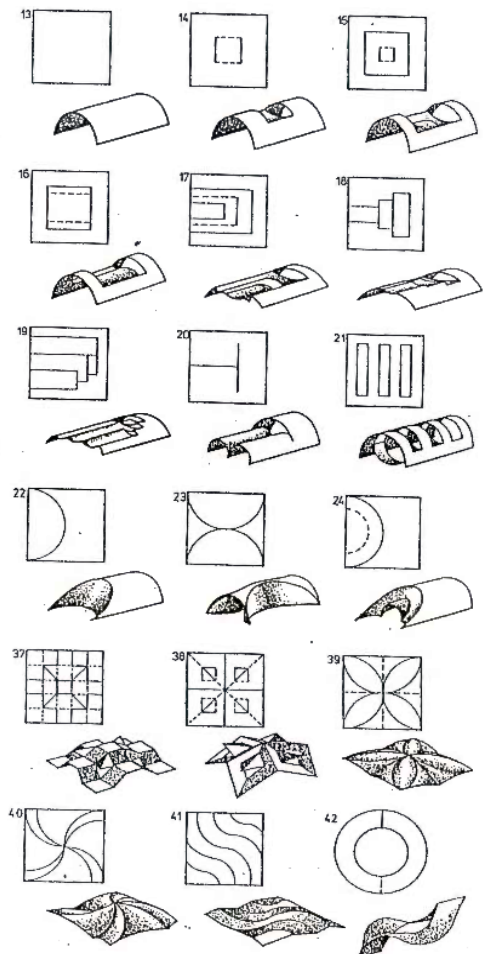

(
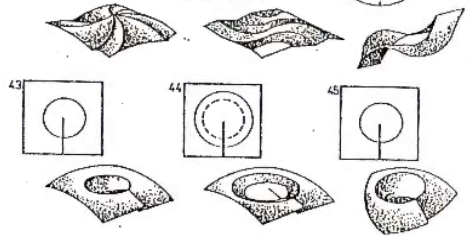

Obr. 4. Abeceda modelovacích prostriedkov (Autor a zdroj: Anton Vranka) 


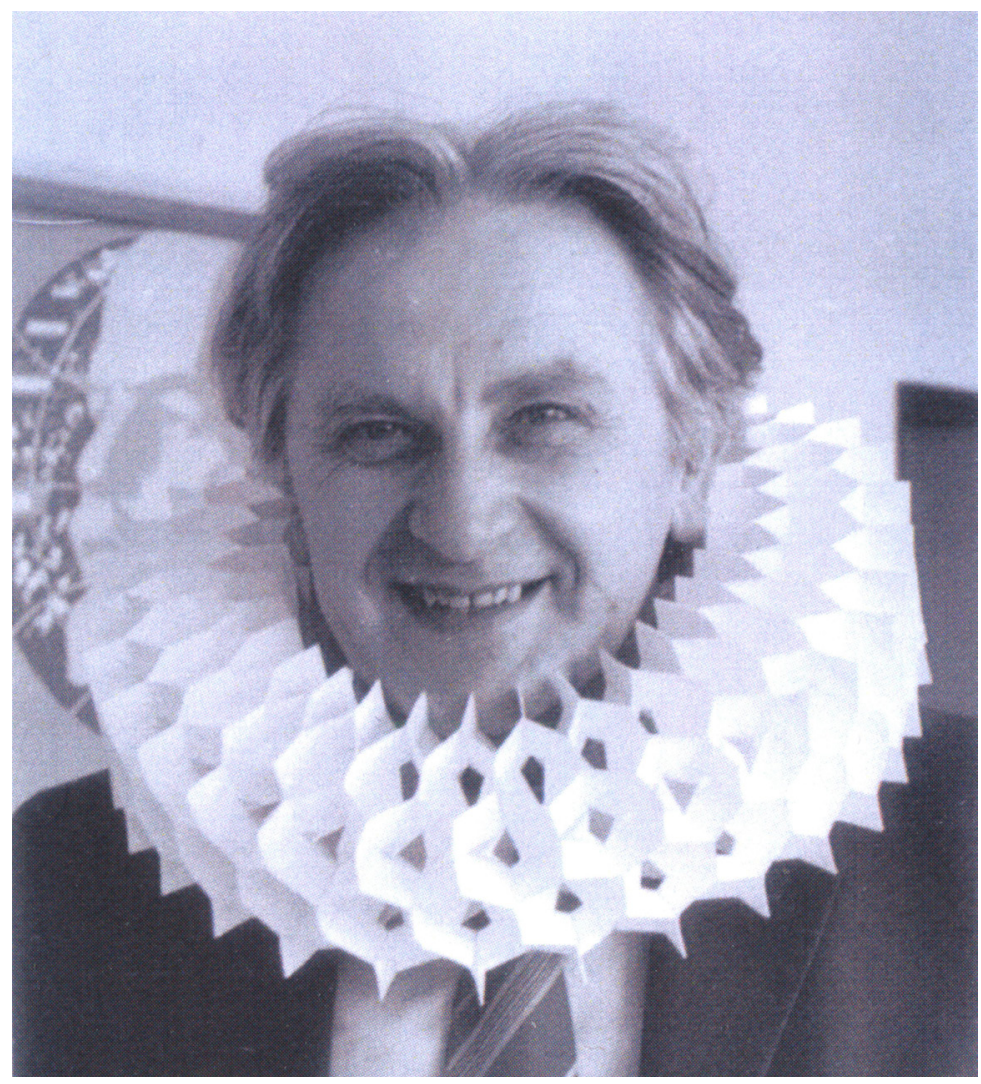

Obr. 5. Anton Vranka a jeden z jeho prakticky využitelných modelov (Autor a zdroj: Anton Vranka)

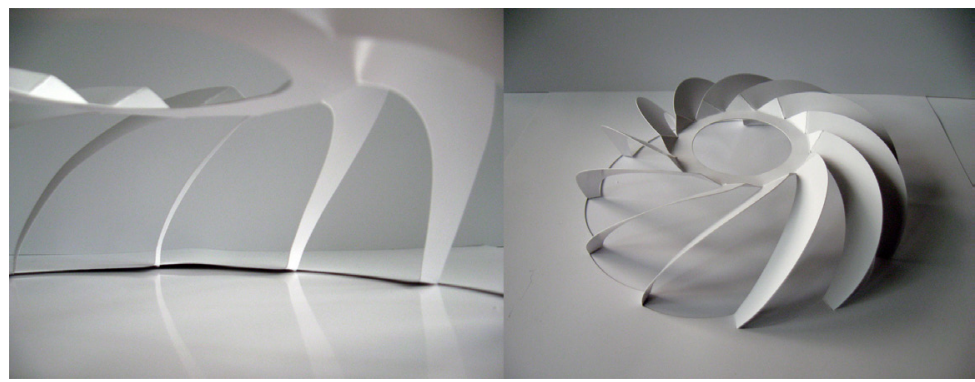

Obr. 6. RES štruktúra inšpirovaná modelom Antona Vranku. Vpravo detailný pohlad do interiéru modelu, vlavo celkový pohlad na model (Autor a zdroj Jakub Novák) 


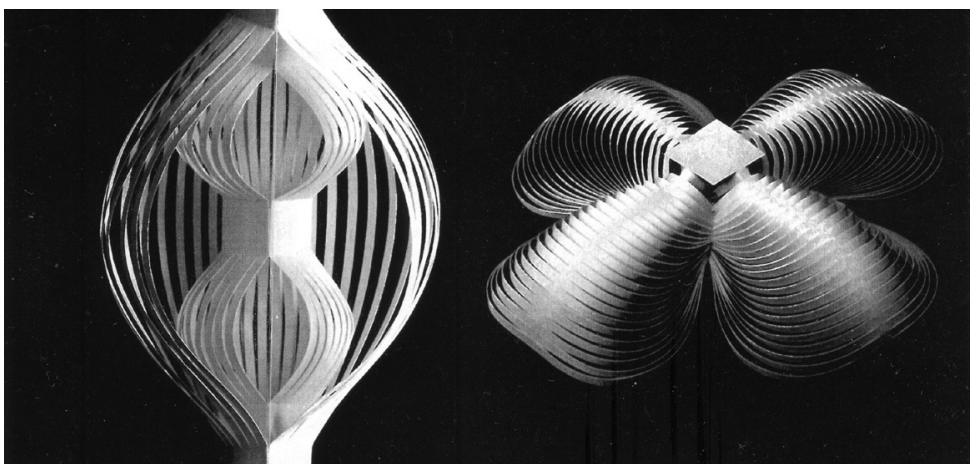

Obr. 7. Dve prúžkové kompozície. Z modelov je cítił náročnost zaistenia ich priestorovej tuhosti ako aj premenlivú povahu vhodnú pre hladanie inšpiratívnej formy (Autor a zdroj: Anton Vranka)

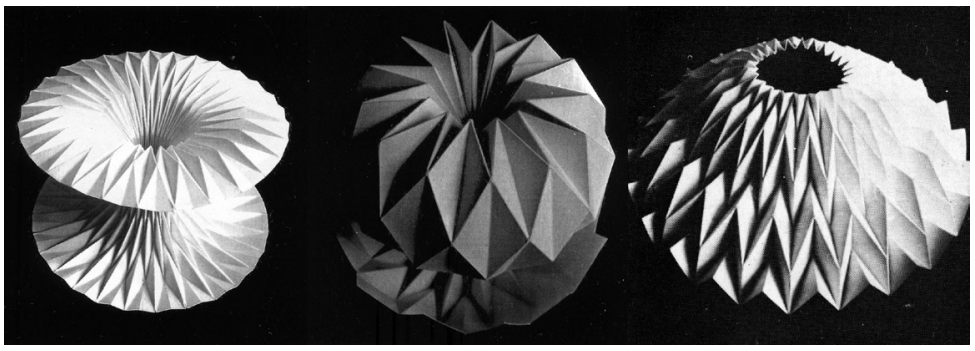

Obr. 8. Kryštalické kupolovité kompozície vytvorené opakovaním reverzného skladu. Vlavo a v strede Yoshimura-Ori. Vpravo Miura-Ori (Autor a zdroj: Anton Vranka)

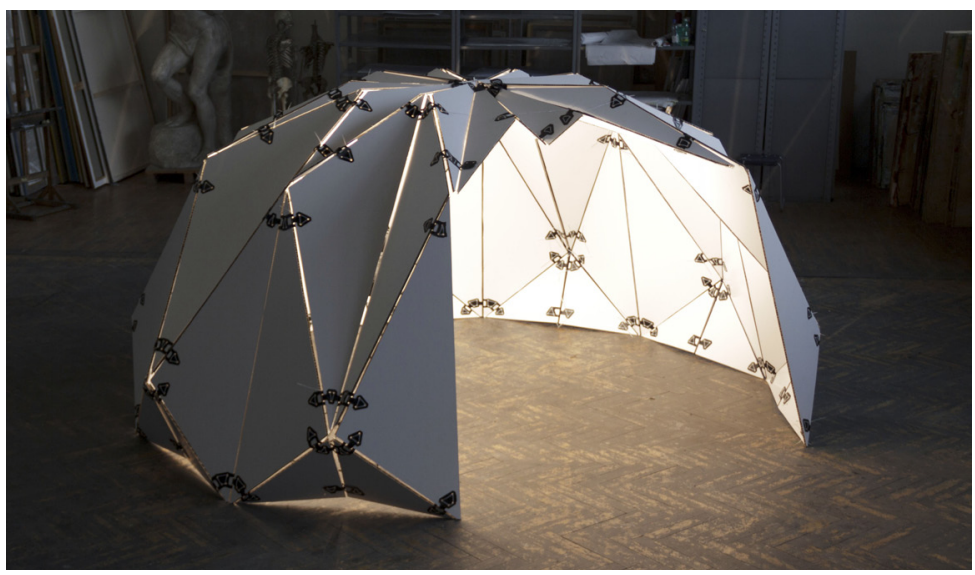

Obr. 9. Skladatelný výstavný pavilón z vylahčených vrstvených dosiek (Autor: Jakub Novák, Jiří Palacký, Samuli Saarinen, foto Jiří Palacký) 


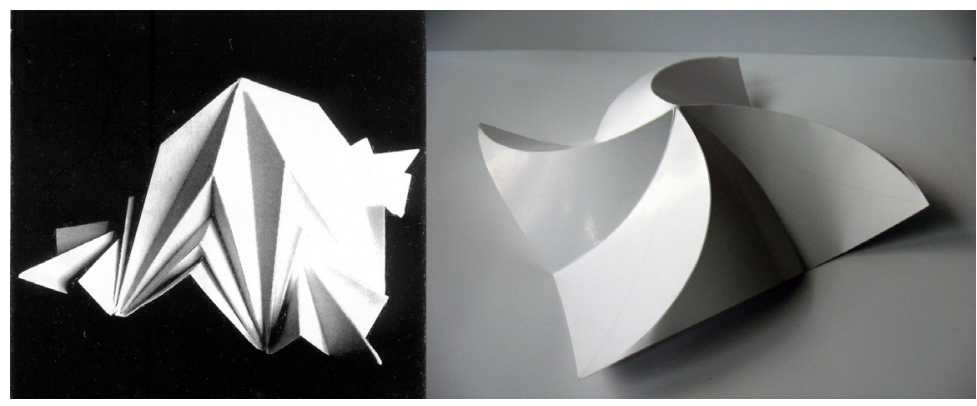

Obr. 10. Dva modely inšpirované bázou waterbomb. Vlavo s pridaním v-skladu (Autor a zdroj: Anton Vranka). Vpravo replika Vrankovho modelu s kružnicovými skladmi (Autor a zdroj: Jakub Novák)

\section{Prameny a poznámky}

BURI, Hans Ulrich, 2010. Origami - Folded Plate Structures [online]. Lausanne [cit. 19. september 2014]. Ph.D. disertation. École Polytechnique Fédérale de Lausanne. Dostupné na: http://infoscience.epfl.ch/record/147983

DEMAINE, Erik D., Martin L. DEMAINE a Koschitz DUKS, 2011. Reconstructing David Huffman's Legacy in Curved Creased Folding. V: Patsy WANG-IVERSON, Robert J. LANG a Mark YIM, ed. Origami 5: Fifth International Meeting of Origami Science, Mathematics, and Education [online]. 21.6.2011. B.m.: CRC Press, s. 662 [cit. 2. júl 2014]. ISBN 978-1-56881-714-9. Dostupné na: http://martindemaine.org/papers/Huffman_Origami5/paper.pdf

HANNA, Brandon H., Jason M. LUND, Robert J. LANG, Spencer P. MAGLEBY a Larry L. HOWELL, 2014. Waterbomb base: a symmetric single-vertex bistable origami mechanism. Smart Materials and Structures [online]. 2014, roč. 23, č. 9, s. 94009 [cit. 21. august 2015]. ISSN 0964-1726. Dostupné na: doi:10.1088/09641726/23/9/094009

LANG, Robert J., 2003. Origami Design Secrets: Mathematical Methods for an Ancient Art. B.m.: Peters. ISBN 978-1-56881-194-9.

LYNN, Greg, ed., 2004. Folding in architecture. Rev. ed. Chichester, West Sussex, Hoboken, NJ: Wiley-Academy. Architectural design. ISBN 978-0-470-09218-7.

MIYAMOTO, Yoshinobu, 2014. Rotational Erection System (RES): Origami Extended with Cuts. V: Toshikazu KAWASAKI, Ryuhei UEHARA, Tomohiro TACHI a Jun MAEKAWA, ed. The 6th International Meeting on Origami in Science, Mathematics and Education: Origami 6: The 6th International Meeting on Origami in Science, Mathematics and Education. B.m.: The 6OSME Program Committee, The 6OSME Organizing Committee, s. 537-544. ISBN 978-1-4704-1876-2. MÜCKENHEIM, Mark a Juliane DEMEL, 2012. Inspiration: contemporary design 
methods in architecture. Amsterdam, The Netherlands: BIS Publishers. ISBN 978-90-6369-267-4.

NOVÁK, Jakub a Jiří PALACKÝ, 2015. Origami ako určujúca metóda priestorovej architektonickej tvorby. V: Martina PEŘINKOVÁ a Martin NEDVĚD, ed. Architecture in Perspective: 7th Architecture in Perspective 2015. Ostrava: VŠB - Technická univerzita Ostrava, s. 75-78. ISBN 978-80-248-3802-1.

RESCH, Ron a Elmer ARMSTRONG, 1971. The Ron Resch Paper and Stick Film [online]. 1971. RESCH, Ron a Elmer ARMSTRONG. https://vimeo.com/36122966:

RESCH, Ronald D., 1973. The topological design of sculptural and architectural systems. V: [online]. B.m.: ACM Press, s. 643 [cit. 30. január 2016]. Dostupné na: doi:10.1145/1499586.1499744

VRANKA, Anton, 2014. Rozhovor o východiskách a metódach tvorby. 10.11.2014

VRANKA, Anton, Jaroslav DRÁPAL, J. S. LEBEDEV, R. ŠÍPKOVSKÝ, M. ŠAFARÍN a E. ANTAL, 1984. Architektonická bionika. V: . Výstava. Praha.

VYZOVITI, Sophia, 2010. Supersurfaces: folding as a method of generating forms for architecture, products and fashion. 6 th printing. Amsterdam: BIS publ. ISBN 978-90-6369-121-9. 